\title{
What vegetable oils and proteins for 2030 ? Would the protein fraction be the future of oil and protein crops? ${ }^{\star}$
}

\author{
Etienne Pilorgé ${ }^{\star \star}$ and Frédéric Muel \\ Terres Inovia, Institut Technique des oléagineux, des protéagineux eu du chanvre, 1 Av L. Brétignières, 78850 Thiverval-Grignon, France
}

Received 5 April 2016 - Accepted 7 June 2016

\begin{abstract}
To support the reflections of the French professionnels of vegetable oils and proteins, a foresight study was carried out to 2030 horizon (15 years), to shed light on the opportunities that will draw the oilcrops and grain legumes, and the areas of growth for the French and European vegetable oil and protein sector. The thinking was organized in the form of four different scenarios for 2030, which illustrate different logical evolutions of the context and related key issues, under the pressure of demographic, economic and socio-political constraints. It is clear that the economic value of the protein fraction is a key aspect of the future of oilseeds such as rapeseed, sunflower and soy. However, a saturated market for vegetable oils falls within the trend but is not a certainty.
\end{abstract}

Keywords: Oils / Vegetable proteins / oil crops / grain legumes / food demand / foresight / scenarios

Résumé - Quelles huiles et protéines végétales pour 2030 ? La fraction protéique est-elle l'avenir des oléoprotéagineux? Pour soutenir les réflexions des professionnels des filières françaises des huiles et protéines végétales, une étude prospective a été menée à horizon de 15 ans (2030), visant à apporter des éclairages sur les débouchés qui tireront les productions oléagineuses et protéagineuses, et sur les pôles de croissance du secteur des huiles et protéines végétales français et européen. La réflexion s'est traduite sous la forme de 4 scénarios contrastés pour 2030 qui se font l'illustration de différentes logiques d'évolution du contexte et des enjeux majeurs, dans le jeu des contraintes démographiques, économiques et socio-politiques. Il apparaît évident que la valorisation de la fraction protéique est un aspect essentiel de l'avenir des oléoprotéagineux que sont le colza, le tournesol et le soja. Toutefois, un marché saturé en huile relève de la tendance mais non de la certitude (the full text is available in French on http://www.ocl-journal.org/).

Mots clés : Huiles / protéines végétales / oléagineux / protéagineux / demande alimentaire / prospective / scénarios

\section{Introduction}

What will be the outlets that pull the French oil and protein crops within 15 years, in 2030 ? What will be the areas of growth for the French and European oilseed sector? What could be the "consequences" of these developments for the actors of the French oil and proteins industry, from the genetic crop improvement to the transformation of the production, and marketing of products?

The reflection we develop in this article was launched by the professionals of the French sector of vegetable oils and proteins, who were wondering about the changes in the relative economic value of oil and protein fractions in oilseed crops. The "protein" fraction, according to the traditional meaning in the industry, refers to oilseed meal obtained from the seeds after oil extraction, which is a "high protein material", where proteins are associated with other constituents of the seeds (cells walls, skins and shells, etc.). In the present article, we

\footnotetext{
* The french version is available in "online material".

$\star \star$ Correspondence: e.pilorge@terresinovia.fr
}

shall consider masses of pure protein, only way to compare materials from different origins and different proteins contents.

This questioning renews the foresight studies conducted in the 1990s (Sébillotte et al., 2002, 2004). The peculiarity of the oilseed crops is indeed to be both rich in oil and protein, and if their main product has long been oil, recent times have seen a rebalancing of the economic value of the two co- products, oil and oilseed cakes. It should also be recalled that the large-scale development of oil and protein crops in Europe was initially motivated by the American embargo on soya meal in 1973 and by the awareness of the dependence of European livestock farming regarding protein raw materials. The 1970s and 80s saw a boom of oilseed rape, sunflower and peas, and to a more limited extent, soybeans. However, the European market has always been very open to import vegetable proteins (soya meal and substitute products to cereal), because of the Blair House agreements, and the European production of plant proteins have lost momentum in the 1990s following the decoupling of aid from production and the gradual disappearance of incentives on these crops (Thomas et al., 2013). The history of 
oil and protein crops then diverged, oilseed crops maintaining some competitiveness through the development of biodiesel (as technical solutions were ready, they emerged as an unexpected solution to occupy and develop the fallow imposed by the former CAP reform of 1992, as industrial fallow). This development, based on rapeseed mainly, also allowed providing significant amounts of oilseed cakes resulting in an improvement of the protein balance of France, whose soybean meal imports were partly replaced by domestic rapeseed and sunflower meals. By cons, despite their agronomic interest, the economic competitiveness of grain legumes gradually lost steam.

Questioning "vegetable oils and proteins" thus brings back to the fundamental historical development of oil and protein crops in a Europe that is still very dependent on imports for its supplies of vegetable protein (Visser, 2014). But with a backdrop of a major economic change: when soy is still the market leader in plant proteins, it had to give way on oils, faced with the development of palm oil in Asia (Lecomte et al., 2013).

Given this Asian dynamic competitor, which produces more than 4 tons of oil per hectare per year when a rapeseed crop produces about $1.5 \mathrm{t} / \mathrm{ha}$, the protein fraction is obviously part of the future of the oilseed crops. But is it that simple? The question needs to be reformulated in view of the demand in both in quantities and qualities. Oils and vegetable proteins (and their origin commodities) are among the most traded agricultural commodities in the world: over $50 \%$ of global oilseed production is exchanged, when only a third of the sugar and $10 \%$ of cereals are (Mittaine and Mielke, 2013). The question must be addressed, for part of it, at global scale. As seen in the case of biofuels, "regional", European and national policies can strongly direct productions. It is therefore necessary to consider these different scales, world, European and national, to respond to questions about the future of French and European oilseed crops.

The rise of the climate change issue is another major change, to consider in its different aspects: political aspect, since it motivates national policies or international agreements, a societal aspect since it is likely to influence consumer behavior or induce specific requests from the society, and finally physical aspect when it is translated into physical phenomena that influence the status of the natural resources and the efficiency of the agriculture and fisheries.

\section{A working methodology based on the analysis and a synthetis in the form of scenarios}

The reflection was organized along the lines of strategic foresight methods developed by Godet (Godet, 2007), and has produced four scenarios. The time horizon was set at 15 years in 2030: it is the horizon of the strategic investment of economic actors (breeding programs, changing industrial processes and related amortization, ...) and it also allows escaping from temporary elements of the short term. A first step was to describe the "prospective system", by situating the heart of the vegetable oil and protein system and its components in all factors of context. This first inventory identified 59 relevant factors including 25 demand- driven and 19 on offer, divided into 9 dimensions (Society, Food, Industry, Institutional, agricultural production and animal farming, R\&D, Economy and Markets, Environment and resources, policies and regulations). The working group eventually developed a representation of the flow diagram of vegetable oils and proteins and their products, linking 21 elements of the agro-industrial system of oils and proteins involved in the flow of materials, in a surrounding context described through 13 environment factors, or "regulators". Then, the various elements of this system were the subject of an information review based on the contributions of experts and bibliographic research. The analysis of past and present dynamics led the working group to make assumptions (145 in total) for the future, in the trend or in rupture, for each factor or key variable.

The construction of the structure of the scenarios was done using the method called "morphological analysis", which consists in assembling assumptions about different dimensions or variables of the system by empirical judgment of the consistency, each scenario being based on one or more driving assumptions. The nature of questioning led us to favor the entry by the quantitative and qualitative demand for oils and proteins, which has guided the choice of driving assumptions. From these choices, the construction of scenarios is based on the balance of supply to demand, that is to say the ability of the global production system to meet the demand within defined context conditions. This is the case in reality: we do not consume what is not produced, and what is produced is always consumed in one way or another, including losses or wastage.

Several elements are particularly critical to this balance: on one hand demographics, a major factor of the changes in demand, and on the other hand the evolution of crop yields. Another key element, the changes in eating habits and resulting diets, regarding the consumption of animal products which are linked to the level of the economic growth, the whole being more or less regulated and managed by policies. The consumption of animal products is particularly critical in so far as the production of animal proteins requires on average 5 times more vegetable proteins (average conversion rate of 5 to 1 ). Some assumptions play on the qualities of the material to produce to meet demand: this is the case for example of allowing or not the use of antibiotics and GMOs in animal feed, which determine the quality of the vegetable proteins to provide (Fig. 1).

Table 1 Shows the first 5 levels of assumptions assembly, that determine the overall level of demand and socioeconomic tone, giving the thread of each scenario.

In practice, the assumptions are summarized in a matrix where each row is devoted to a dimension or a variable of the system, and includes the various assumptions for this variable.

The scenarios were then written in text form, in a detailed manner (about 10 pages each) from these structures, this writing being a first step of consistency check. A quantitative assessment was then carried out to check the consistency of the assemblies of assumptions made on variable estimates and orders of magnitude.

The work of reflection for the development of the scenarios' structure has mobilized a group of 18 experts from 


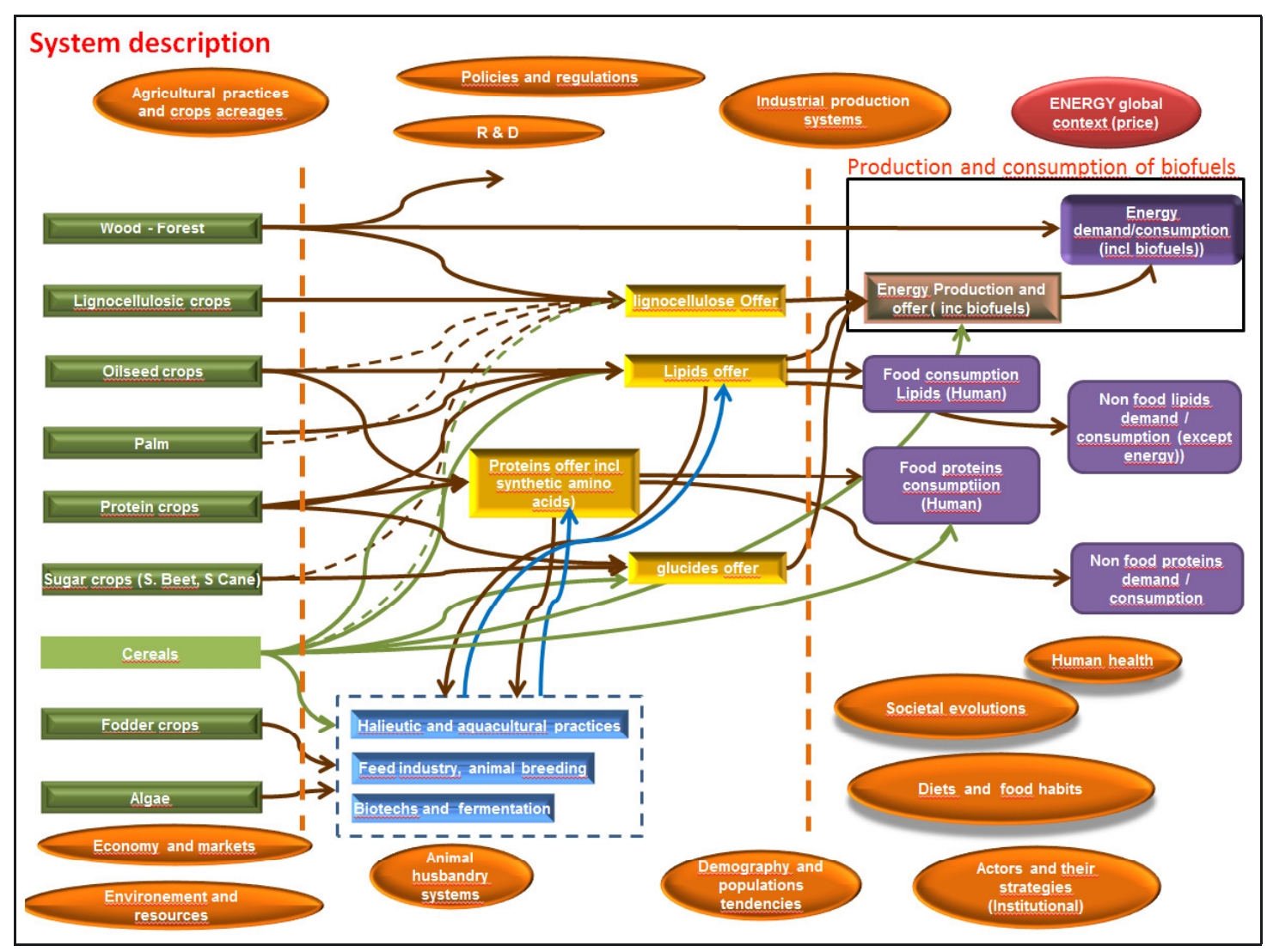

Fig. 1. The protein-oil system and its context.

business, interprofessional organizations and research and development institutions, which met 13 times from September 2013 to October 2014, for developing a prospective vision in the form of 4 different scenarios.

\section{Four prospective scenarios given as thinking framework}

These four scenarios illustrate different logics of context evolution, and major issues for the reflection of sector policy makers, leading to the identification of areas for pre-active or proactive actions. A brief summary focused on the demand aspects is given here. It cannot reflect the richness of the hypotheses developed in the detailed text.

\subsection{Scenario 1: "Towards Chaos": Economic and political crisis, food tensions, competitions and growing inequalities}

Facing the strong world population and the tangible effects of climate change, the situation is tense to meet food demand. The economic crisis, generating a climate of tension, insecurity and general impoverishment, does not allow the adoption of international agreements on long-term policies (resource conservation, environment, renewable energy, health, ... ).
Animal proteins are a luxury: their consumption is declining in Europe (where the vegetable proteins are better accepted) and tops out elsewhere. With depressed energy prices, biofuels of first generation remain only to use the oil surplus from palm and soy. The rising cost of food leads to increased use of plant proteins. Regarding vegetable oils, palm oil, abundant and inexpensive, dominates the food business.

\subsection{Scenario 2: "The might of the blocks": Regional policies and bilateralism}

Climate change leads to contrasting effects between regions: due to divergent interests, international negotiations are blocked. Europe and the most affected countries implement unilateral policies against climate change, in a latent protectionism atmosphere. Yields - and global production - increase slowly, for a population that is growing by $15 \%$ between 2013 and 2030. The economy keeps pace with the population and the standard of living is maintained on average. In Europe, society's demand on sustainability and health led member States to develop renewable energy (including biofuels), to better exploit the potential of territories and to regulate through restrictions on greenhouse gas emissions (GHG) and carbon tax. Biorefinery at regional scale and non-food uses of agricultural resources are essential. Veganism rises in Europe while consumption of animal protein progresses in China and Africa. Palm oil is used in chemistry, especially in Southeast Asia, and for biofuels. 
Table 1. Driving and main secondary assumptions.

\begin{tabular}{|c|c|c|c|c|c|}
\hline $\begin{array}{c}\text { MAIN } \\
\text { ASSUMPTIONS }\end{array}$ & 2013 & SC1 Chaos & SC2 Blocks & SC3 Trust & $\begin{array}{l}\text { SC4 Climate } \\
\text { rupture }\end{array}$ \\
\hline Population & 7.2 & 8.9 & 8.4 & 7.9 & 8.9 \\
\hline $\begin{array}{l}\text { Agricultural yields } \\
\text { progress }\end{array}$ & & stagnation & weak & moderate & stagnation \\
\hline $\begin{array}{c}\text { Per capita animal } \\
\text { proteins consumption }\end{array}$ & & low & moderate & high & low \\
\hline $\begin{array}{l}\text { Political behaviours } \\
\text { regarding global change }\end{array}$ & & $\begin{array}{l}\text { passivity and everyone } \\
\text { for himself }\end{array}$ & blocks policies & cooperation & cooperation \\
\hline Economic growth & & weak & moderate & high & moderate \\
\hline $\begin{array}{l}\text { Petroleum price } \\
\$ / \text { barel//\$/ton }\end{array}$ & $105 / / 770$ & $\begin{array}{l}50-70 / / \\
365-511\end{array}$ & $\begin{array}{c}60-80 / / \\
450-610\end{array}$ & $\begin{array}{c}\text { high, and contrasts } \\
\text { between regions } \\
-->135 / 150 \\
/ / 950-1100\end{array}$ & $\begin{array}{c}\text { high, and contrasts } \\
\text { between regions } \\
-->135 / 150 \\
/ / 950-1100\end{array}$ \\
\hline \multicolumn{6}{|l|}{$\begin{array}{c}\text { Animal protein } \\
\text { consumption g/cap/day }\end{array}$} \\
\hline China & 37 & 39 & 46 & 46 & 41 \\
\hline India & 14 & 20 & 21 & 36 & 18 \\
\hline Africa & 14 & 16 & 26 & 26 & 18 \\
\hline Europe & 67 & 49 & 54 & 65 & 36 \\
\hline USA & 70 & 55 & 61 & 66 & 43 \\
\hline rest of the world & 37 & 26 & 31 & 37 & 36 \\
\hline World & 31 & 29 & 34 & 39 & 29 \\
\hline $\begin{array}{l}\text { World Palm oil for food } \\
\text { consumption MT/year }\end{array}$ & 41 & $\begin{array}{l}\text { "more than } \\
200 \text { MT" }\end{array}$ & $42-50 \mathrm{MT}$ & $50 \mathrm{MT}$ & \\
\hline Health policies in Europe & & no & yes & yes & yes \\
\hline $\begin{array}{l}\text { Nutritional } \\
\text { recommendations are } \\
\text { taken into account }\end{array}$ & & no or poorly & yes & yes $->$ oméga-3 & yes $->$ oméga-3 \\
\hline $\begin{array}{l}\text { EU policies } \\
\text { on biofuels }\end{array}$ & & $\begin{array}{c}\text { biofuels } \\
\text { not mandatory }\end{array}$ & $\begin{array}{c}\text { Renewable energy } \\
\text { directive maintained/ } \\
\text { mandatory }\end{array}$ & $\begin{array}{c}\text { Renewable energy } \\
\text { directive maintained/biofuels } \\
\text { not mandatory }\end{array}$ & \\
\hline $\begin{array}{l}\text { Reinforced regulations } \\
\text { regarding sustainability }\end{array}$ & & no & $\begin{array}{l}\text { generalized carbon } \\
\text { tax in Europe }\end{array}$ & yes, standardization & $\begin{array}{c}\text { yes, carbon tax } \\
\text { and standardization }\end{array}$ \\
\hline $\begin{array}{c}\text { GMO } \\
\text { regulations }\end{array}$ & & deregulated & $\begin{array}{c}\text { no crops } \\
\text { no use in Europe }\end{array}$ & $\begin{array}{l}\text { constraints } \\
\text { are lifted }\end{array}$ & $\begin{array}{c}\text { constrainsts are } \\
\text { partially lifted }\end{array}$ \\
\hline $\begin{array}{l}\text { Antibiotics } \\
\text { uses in feed }\end{array}$ & & free & prohibited & prohibited & $?$ \\
\hline $\begin{array}{l}\text { Green chemistry, } \\
\text { biorefinery }\end{array}$ & & stagnating & $\begin{array}{l}\text { strong development } \\
\text { (Asia leader for } \\
\text { oleochemistry) }\end{array}$ & $\begin{array}{c}\text { strong } \\
\text { development }\end{array}$ & $\begin{array}{c}\text { strong } \\
\text { development }\end{array}$ \\
\hline
\end{tabular}

\subsection{Scenario 3: "Trust": International cooperation in preventing climate change}

The Nations sense the threat of climate change and integrate it in their policies, creating an international cooperation to address climate, food and energy challenges, while maintaining free trade. Green Growth is launched, based on advanced R\&D and the establishment of trading standards (on products, processes and production conditions) and accompanying measures, where Europe plays as leader. European consumers are aware of the nutritional recommendations and of the carbon impact of production and consumption modes, and are turning to a low-impact diet. Quite the opposite, the improvement of living conditions linked to moderate population growth and economic affluence leads to increased consumption of animal protein in many countries (Africa, China, but also India) blowing the demand for animal feed. Soy is widely grown for feeding livestock. The oleochemistry and biofuels, driven by an efficient R\&D and a high energy prices, are growing strongly worldwide, especially in Asia from palm oil.

\subsection{Scenario 4: "Climate rupture": Measures for savings and forced cooperation because of climate and food tensions}

The strong growth of the world population and the effects of climate change put agricultural production under pressure 
and cap yields. This leads states to negotiate and cooperate in emergency on environmental policies, at the level of technology transfer and on the distribution of economic efforts between the South and the North. Constraining measures target carbon balances and GHG, playing both on production processes through standardization and on consumption through a generalized carbon tax. Energy is taxed to finance the development of alternative energies. Advances in R\&D are put forward to meet the constraints and generate green growth, opening applications to GMOs, green chemistry, the development of a circular economy with local bio-refinery. Initially driven by economic growth, the development of animal protein consumption proves unsustainable and quickly reaches limits in Africa and Asia. European consumers, made aware of issues of sustainability and health by the authorities, opt for a diet less rich in animal protein.

\section{What developments for vegetable oils and plant proteins outlets in the world?}

The consistency of the scenarios should eventually be verified on the adequacy of supply to demand, that is to say the ability of the global production system to respond to the demand in the conditions specified by the scenarios. This is the case in reality: we do not use what has not been produced, and what is produced is always consumed in one way or another, including losses or wastage.

The quantification of the scenarios is a complicated exercise that allows better understanding some system operating mechanisms. Its main interest lies in the consolidation of the consequences of the choices made in each scenario, a key element for a check of consistency and plausibility.

For this, we have developed a computing spreadsheet to confront the food demand resulting from the assumptions of the scenarios, with the supply end of the vegetable and animal production, whose development must remain within the limits of the physical possibilities of the planet and remain consistent with the principles of the scenario. Indeed, the main entrance for the period is demand, and assumptions on offer were not developed, if we except those on the direct competitors of European oilseeds, namely palm and soybeans. The spreadsheet was constructed to be able to enter the main assumptions developed by the working group, as input variables, and supplement them (especially concerning acreages of the different crop species) to balance demand and supply. Its output variables allow consolidating the consumption of oils and proteins by major categories of sources (plants or animals) and uses (food or feed, non-feed/non-food) and evaluate the necessary surfaces and yields to meet the demand. The spreadsheet also allows evaluating production/consumption balances by large geographic blocks.

The guiding principle was to develop a comparison spreadsheet balancing supply and demand for the current situation, in order to observe the effect of scenario assumptions on demand and then try to balance the scenario, taking into account the assumptions on production and complementing them when necessary. This work will not be developed here.

While most studies on global food needs reason in terms of energy needs (kcal), we chose to reason in terms of proteins: the demand and supply have been translated into masses of proteins (million tons of pure protein). Consistency checks have been made as to the satisfaction of energy needs in a second step only. Demand and supply as oils and fats have also been expressed in tons.

The exercise easily highlighted the missing points of the work of the expert group meetings, for example on the issue of losses and waste, which had not been addressed specifically, and on which no assumptions were made. These elements were incorporated into the calculations so as to take account of their impact.

The changes must be considered from quantitative and qualitative aspect. One approach is to distinguish the major types of uses: vegetable protein for direct human consumption or for animal feed, or for non-food uses; oils for food or nonfood uses, including biodiesel and plant chemistry.

In terms of vegetable oils, we assessed the future demand on the basis of the current trends of consumption of fat increasing with the elevation of living standards (Combris, 2013), translating the assumptions made on economic growth and on the enrichment or impoverishment of populations. By this way, we see that the increase in food demand remains relatively limited compared to the growth capacity of the palm oil production, from 133 million tons edible oil in 2013 to 156-165 million tons in 2030, an absolute increase of 23 to 32 MT depending on scenarios: as long as the expansion of palm oil, with very competitive production costs, goes on, there will be oil in excess, more or less important compared to food needs, and especially as the soybean crop should be driven by the demand for protein, leading to quantities of soybean oil on the market. We can therefore expect strong competition in the vegetable oil market with two heavyweights: the palm supported by its strong competitiveness in production cost per ton, but which may be hampered in its development by environmental or nutritional considerations, and soybean oil, driven by the strong demand for protein for animal feed.

The conditions for the development of non-food uses of oils are very different between scenarios: excess oil may be real, with need to dispose of surpluses for cheap non-food outlets (biofuels in Scenario 1 "chaos"), or artificial in case of real economic dynamics of non-food uses, either from a high energy market (scenario 3 "Trust"), or from technological innovation and/or incentives policies (scenario 2 "Blocks"). In the case of scenario 4 "climate rupture" excess oil over the food needs remains relatively limited in a context where the resources scarcity, actual or of regulatory origin, makes nonfood uses economically attractive.

This shows that if the strong growth of oil production seems to be a trend, the excessive nature of the production is obvious in scenario 1 only, where uses at low price only are possible, due to economic depression. In other scenarios, noble non-food uses ensure alternatives for consumption and growth in an unbalanced world between available resources and the needs of an active economy. However, in the context of scenario 1 depressed market, the development of palm could be challenged by soybean oil, as co-product from the production of protein for livestock. In scenarios with high oil prices and encouraging bio-based products, palm development could be based on green chemistry, provided that production is 


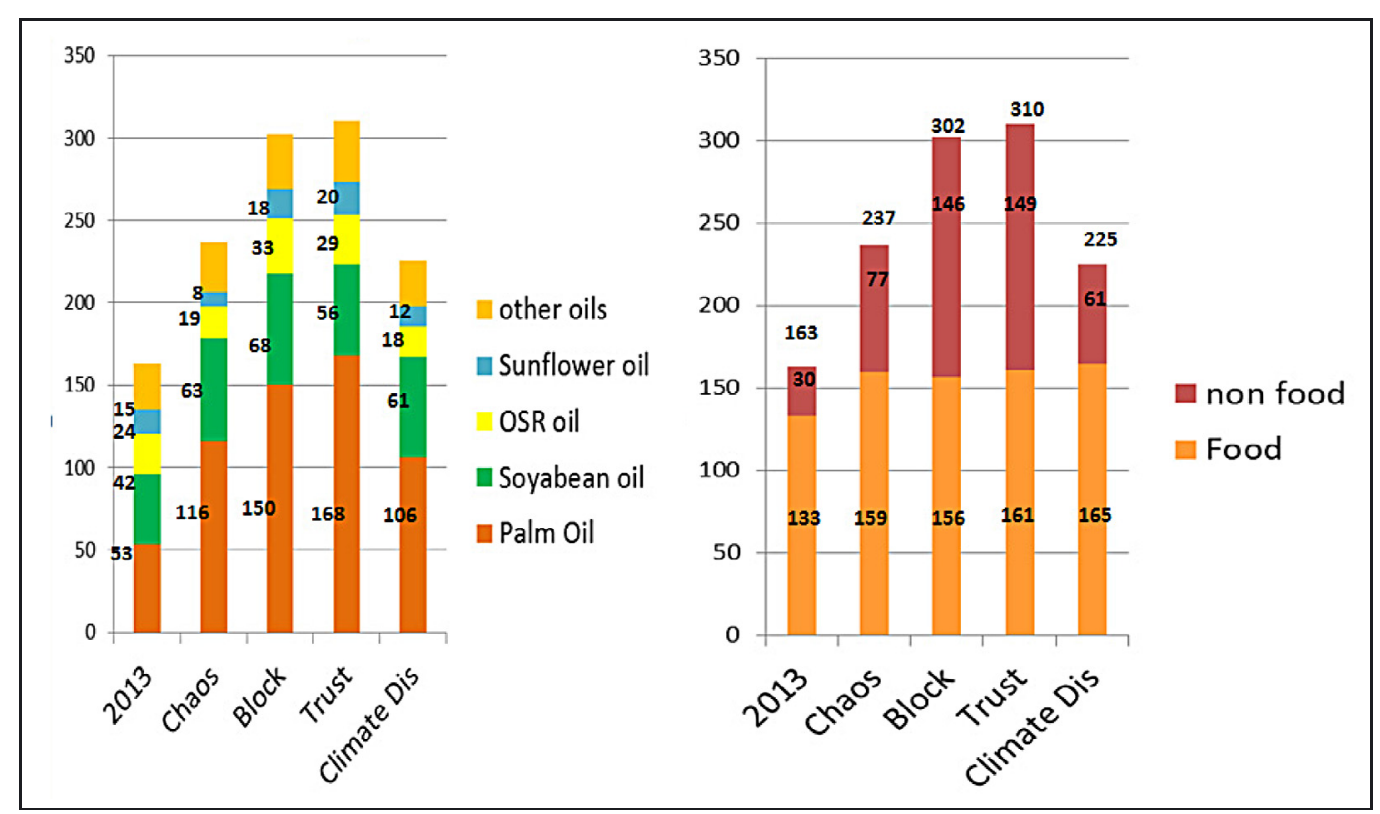

Fig. 2. Estimates of global production and use of vegetable oils in the different scenarios.

compatible with environmental constraints related to climate change: it could then be held back by the question of deforestation, at least in regulated scenarios (scenarios 2-4). The labeled products could then become important (Fig. 2).

That said, the various vegetable oils are not completely substitutable and their technical and nutritional characteristics must also be taken into account.

Their omega- 3 fatty acids content is an example: the needs in short chains omega 3 fatty acids (alpha linolenic acid) is estimated at $2 \mathrm{~g} /$ day ( $1 \%$ of energy intake) per capita, i.e 5.2 MT for the current world population. The current production of soybean oil (42.2 MT) and rapeseed oil (24.2 MT) leads to estimate the production of short chains omega-3 around 4.5 MT. The needs are probably not covered today, or just covered taking into account other sources.

Covering omega-3 needs seems to be no difficulty only in scenario 3 "Trust", with the lowest population. In the other scenarios, this raises at least the question of the future of soybean and rapeseed oils production, which would be better kept, or even promoted, for human consumption, considering their recognized nutritional characteristics (polyunsaturated fatty acids) which are now an advantage over palm oil (oleic mass production of palm oil being considered unlikely by 2030). If the situation in alpha-linolenic gets tense (aging populations will magnify the phenomenon), should rapeseed production shift towards low linolenic varieties? The content of alpha-linolenic could become a real asset and help maintain the rapeseed production.

Regarding long chain omega 3 EPA/DHA, the problem increases in all scenarios with the depletion of fishery resources and the development of aquaculture: the production of EPA/DHA through white biotechnology or GMO crops (GMOs outside Europe in scenario 2) may be required, at least if we try to cover the needs of the world population up to the nutritional recommendations level, which is already difficult to achieve on average.
Table 2. Estimates of vegetable protein quantities to meet demand in the four scenarios.

\begin{tabular}{cccccc}
\hline & 2013 & SC1 & SC2 & SC3 & SC4 \\
\hline $\begin{array}{c}\text { Million tons } \\
\text { of protein }\end{array}$ & Present & Chaos & Blocks & Trust & $\begin{array}{c}\text { Climate } \\
\text { rupture }\end{array}$ \\
\hline Feed fodder & 112 & 153 & 148 & 162 & 129 \\
\hline $\begin{array}{c}\text { Feed "rich } \\
\text { in proteins" }\end{array}$ & 227 & 264 & 315 & 316 & 261 \\
\hline Food & 139 & 174 & 159 & 146 & 168 \\
\hline $\begin{array}{c}\text { Ratio Food/ } \\
\text { (Feed rich. + Food) }\end{array}$ & 0.38 & 0.40 & 0.33 & 0.32 & 0.39 \\
\hline
\end{tabular}

The demand for vegetable proteins was assessed as protein masses (tons of proteins), considering the protein content of different vegetable or animal sources. The overall growth of food proteins of animal origin is estimated between 11 and 32 million tons of protein depending on the scenario, 26 to $39 \%$ more than in 2013. The multiplier effect of the consumption of animal products appears very clearly because of the conversion of animal proteins into vegetable proteins needed to produce them: from +52 to +141 MT (including fodder) or +16 to $+41 \%$ depending on the scenario. Whatever the scenario, the growth of plant proteins for animal feed is high and exceeds the human food destination, but is much more pronounced in scenarios 2 "Blocks" and 3 "Trust", more demanding in animal protein, than in scenarios 1 "Chaos" and 4 "Climate rupture" where the increase in materials rich in protein (fodder excepted) is almost evenly distributed between animal feed and human food (Tab. 2).

These figures show that significantly inflecting the trend of high consumption of animal products would require drastic measures, certainly beyond the spontaneous changes in eating habits.

Regarding vegetable protein for human nutrition, scenario 3 'Trust", which combines economic growth, low 


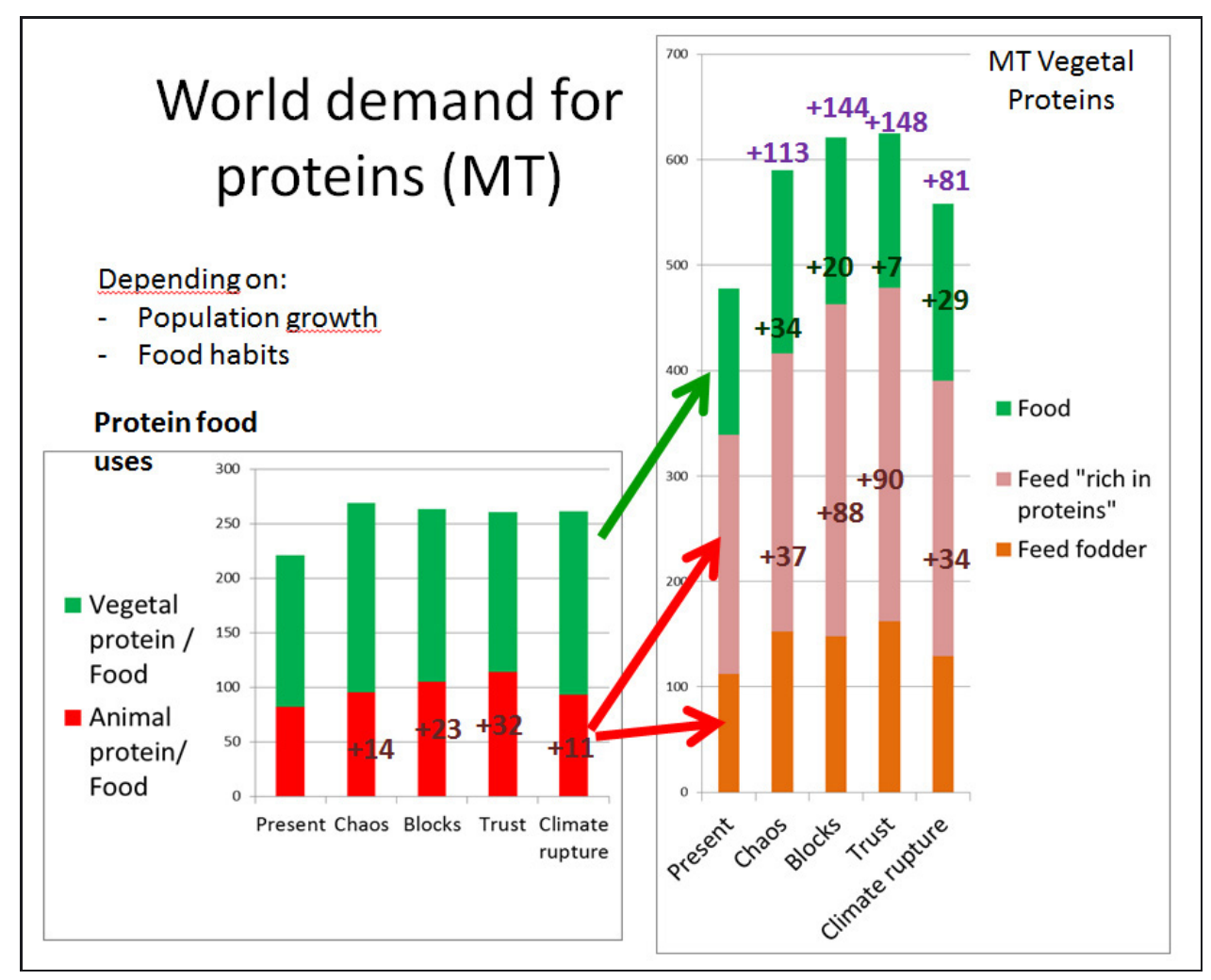

Fig. 3. Estimates of demand for proteins in the 4 scenarios.

population growth and "meat" dietary habits shows the lowest increase (+7 MT protein/ $+5.2 \%$ ), followed by scenario 2 "Blocks" (20MT /+14\%). In scenarios 1 "Chaos" and 4 "Climate rupture", the increase exceeds 20\% (+34 and + 29 MT)

The ratio "Food" proteins/Concentrated "Feed + Food" proteins (excluding fodder) shows a discrepancy between scenarios 1 and 4 where the relative weight of vegetable protein for human consumption increases, and scenarios 2 "Blocks" and 3 "Trust" where it decreases.

The vegetable proteins that would be provided in the various scenarios are not targeted to the same uses or in the same proportions, and in rather different market conditions:

- Scenario 3 "Trust" demands masses of proteins for animal feed, without differentiation on GMO origin regarding Europe, but with more regular qualities, notably because of the disappearance of antibiotics in animal production. The growth of plant proteins for direct human consumption is the lowest in this scenario, but also more qualitative from a nutritional point of view, and more "technological" with an R\&D driven by the needs of wealthy clients and/or with special needs (elderly, athletes). The vegetable protein is desired for nutritional and technological properties and image.

- Scenario 2 "blocks" demands for livestock protein masses too, but this time with differentiation of Europe, both on the GMO origin and on the nutritional quality through technically more restricted feed system. The growth of plant protein for human consumption is higher than in scenario 3 but globally with the same "nutritional and technological" profile.
- Scenario 1 "Chaos" demands protein masses for animal husbandry, but with feeding systems fairly standard and with few constraints on technical practices, guided mainly by production costs reduction. As for vegetable protein for human consumption, their development is driven by the preoccupation to offer cheap alternatives to animal proteins to impoverished populations, either as raw or minimally processed vegetable products, either as vegetable industrial products or combining animal and vegetable proteins. The role of plant protein is primarily economic.

- in scenario 4 "climate rupture", the technical constraints on animal feeding are at an intermediate level and above all guided by the carbon balance sheets. Regarding food, the quality/price ratio is more strongly driven by the dietary and nutritional considerations and health concerns, and respect for the environment (Fig. 3).

At last, the development of aquaculture is a constant of the scenarios that induces specific vegetable protein needs.

\section{Will the production be able to follow the demand?}

The assessment of the demand in different contexts is not enough: we must ensure that supply can follow, taking into account the constraints on production. The calculations allowed us to assess the needed acreage to meet the levels of demand for our scenarios in 2030, favoring the production of the protein fraction (the rarest one), and ensuring sufficient production of the other diet components (Tab. 3). 
Table 3. Estimates of orders of magnitude of cultivated acreage development required in the 4 scenarios.

\begin{tabular}{lccccc}
\hline Acreages in million ha & 2013 & SC1 & SC2 & SC3 & SC4 \\
\hline World cultivated acreage, foddder crops excluded & 1287 & 1461 & 1472 & 1362 & 1457 \\
World cultivated acreage, fodder crops included & 1534 & 1767 & 1764 & 1656 & 1731 \\
World cultivated acreage variation, fodder crops excluded & & 174 & 185 & 75 & 170 \\
Cultivated acreage variation fodder crops included & & 233 & 229 & 122 & 197 \\
\hline
\end{tabular}

Table 4. Composition, protein and oil yields for major crops (source: FAO).

\begin{tabular}{|c|c|c|c|c|c|c|c|c|c|c|c|}
\hline \multicolumn{6}{|c|}{$\begin{array}{l}\text { Composition, yields, oil and protein } \\
\text { yields for main crops/yields in } \mathrm{T} / \mathrm{ha}\end{array}$} & \multicolumn{3}{|c|}{ World (FAO) } & \multicolumn{3}{|c|}{ Europe (FAO) } \\
\hline Crop & $\%$ & & $\begin{array}{r}\% \text { on } \\
\text { fo }\end{array}$ & $\begin{array}{l}\text { roduct } \\
\text { use }\end{array}$ & & $\begin{array}{c}\text { Average } \\
\text { yield } \\
2009-2013\end{array}$ & $\begin{array}{c}\text { Aver } \\
\text { oil } \\
\text { yield }\end{array}$ & $\begin{array}{c}\text { Aver } \\
\text { protein } \\
\text { yield }\end{array}$ & $\begin{array}{c}\text { Average } \\
\text { yield } \\
\text { 2009-2013 }\end{array}$ & $\begin{array}{c}\text { Aver } \\
\text { oil } \\
\text { yield }\end{array}$ & $\begin{array}{c}\text { Aver } \\
\text { protein } \\
\text { yield }\end{array}$ \\
\hline & DM & starch & oil & protein & others & $\mathrm{t} / \mathrm{ha}$ & & & & & \\
\hline soya & $89 \%$ & $5.7 \%$ & $18.9 \%$ & $35.2 \%$ & $29 \%$ & 2.5 & 0.5 & 0.9 & 2.65 & 0.50 & 0.93 \\
\hline sunflower & $93 \%$ & $1.2 \%$ & $44.5 \%$ & $15.4 \%$ & $32 \%$ & 1.2 & 0.5 & 0.2 & 2.33 & 1.04 & 0.36 \\
\hline rape & $92 \%$ & $3.1 \%$ & $42.6 \%$ & $19.3 \%$ & $27 \%$ & 1.9 & 0.8 & 0.4 & 3.56 & 1.51 & 0.69 \\
\hline lupin & $89 \%$ & $0.0 \%$ & $8.9 \%$ & $33.8 \%$ & $47 \%$ & 1.3 & 0.1 & 0.4 & 1.63 & 0.15 & 0.55 \\
\hline pea & $87 \%$ & $44.4 \%$ & $1.0 \%$ & $20.7 \%$ & $22 \%$ & 1.6 & & 0.3 & 3.82 & & 0.79 \\
\hline fababean & $87 \%$ & $38.7 \%$ & $1.2 \%$ & $25.1 \%$ & $22 \%$ & 0.8 & & 0.2 & 3.92 & & 0.98 \\
\hline lentils & $88 \%$ & $40.4 \%$ & $1.4 \%$ & $23.8 \%$ & $23 \%$ & 1.1 & & 0.3 & 1.59 & & 0.38 \\
\hline maize & $87 \%$ & $63.7 \%$ & $3.6 \%$ & $7.9 \%$ & $12 \%$ & 5.2 & 0.2 & 0.4 & 9.36 & 0.33 & 0.74 \\
\hline wheat & $86 \%$ & $59.3 \%$ & $0.0 \%$ & $10.8 \%$ & $15 \%$ & 3.1 & & 0.3 & 7.15 & & 0.77 \\
\hline Forage and Silage alfalfa & $20 \%$ & $0.0 \%$ & $0.0 \%$ & $4.0 \%$ & $16 \%$ & 22.0 & & 0.9 & 42.50 & & 1.70 \\
\hline Forage and silage, maize & $23 \%$ & $3.5 \%$ & $0.6 \%$ & $1.9 \%$ & $17 \%$ & 34.6 & 0.2 & 0.7 & 39.60 & 0.24 & 0.75 \\
\hline Forage and silage, sorghum & $28 \%$ & $0.0 \%$ & $0.5 \%$ & $2.3 \%$ & $25 \%$ & 20.4 & 0.1 & 0.5 & 35.20 & 0.19 & 0.81 \\
\hline Forage and silage, rye grass & $17 \%$ & $0.0 \%$ & $0.0 \%$ & $2.5 \%$ & $14 \%$ & 10.3 & & 0.3 & 9.60 & & 0.24 \\
\hline Forage and silage, clover & $17 \%$ & $0.0 \%$ & $0.5 \%$ & $4.2 \%$ & $12 \%$ & 34.1 & 0.2 & 1.4 & 23.20 & 0.11 & 0.97 \\
\hline
\end{tabular}

Given the assumptions made, between 75 and 185 million additional hectares would be needed to meet the needs for "monogastric" feed and from 122 to 233 including forage crops.

The continuation of the pace for land reclamation observed between 1961 and 2000 (with an average rate of 3.75 Mha/year) would add 67.5 million hectares by 2030 . The reverse calculation gives the land reclamation rate required for the consistency of each scenario: 12.9 Mha/year, 12.7 Mha/year, 6.4 Mha/year, 10.9 Mha/year, i.e respectively $3.5,3.4,1.7$ and 2.9 times the rate of the past decades. Although other foresight exercises have envisioned tripling the land reclamation rate by 2050 , the likelihood of those figures is subject to discussion, especially with depressed economy, unsuitable for investment, which is the case of scenario 1 "Chaos". Furthermore, the limit of these extensions of cultivated acreage also lies in the deforestation and its compatibility with the fight against the greenhouse effect, even if part of the effort can be done without deforestation (INRA CIRAD, Agrimonde).

Pursuing further the reflection shows that balancing supply and demand always questions the development dynamics and sometimes asks to reconsider some assumptions with lower levels, particularly in terms of ambition on improving the diets protein content in developing countries (our assumptions already considered a reduction of animal protein consumption, which is very high today, in OECD countries). The strategic aspect of improving yields at world level (particularly protein yields in $\mathrm{kg} / \mathrm{ha}$ ) is highlighted, and the importance of climate risk in terms of global average yields evolution. Some agronomic levers can be mobilized, eg multiple cropping, or cropping intensification (increasing the number of crops per year on the same field), but only within the limits of the availability of other inputs or resources, including water. Progress will be needed to decrease losses in the food chain upstream (and downstream) for economic competitiveness, food security and environmental impact reasons altogether. Given the magnitude of the gaps to be filled, the answers will necessarily be multiple and complex.

Meeting the needs will be much harder for vegetable proteins than for oils and fats, and will require to play on all levers: food consumption level, waste reduction, productivity. So it is very clear that protein production will be an important part of the future competitiveness of oilseed crops.

\section{How changing context might affect the competitiveness of different crops, sources of oils and proteins?}

The scenarios highlight issues that come in technical and scientific challenges that the different crops and agro-industrial sectors related to them can meet more or less easily.

Some of these issues and challenges are common to all scenarios: it is the case for the protein economy, that is to say both protein productivity issues and use efficiency of the produced proteins (Tab. 4). 
The protein yield per hectare is a fairly discriminating criterion between species, which will play differently depending on the performance of crops in the different parts of the world. Only forage legumes such as clover or alfalfa exceed a ton of protein per hectare today. If these species remain mostly devolved to ruminant animals, protein extraction can change things: protein extracts of alfalfa start, for example, to be marketed for monogastric animals. In contexts of high protein demand, and by means of advances in R\&D and sectorial organization, forage legumes competitiveness could increase, both in the field of conventional feed and in the area of concentrates and protein isolates. Then come pulses and soybeans, which reach protein yields of around one ton/ha, followed by rapeseed with protein yields of 0.6 to 0.7 tons/ha, and sunflower. Their competitiveness will also come from their co-product, oil or starch.

In the scenarios that show a significant development of the biorefinery (scenarios 3 "Trust" and 4 "Climate rupture"), the ability to easy extraction of vegetable protein may be an advantage. From this point of view, the pulses already fall in well-established industrial processes, while the extraction of protein from oil crops species will require changes in current industrial processes.

The efficiency of proteins use in animal feed is already a strong competitiveness criterion whose importance is expected to increase, both for economic and environmental reasons: on this criterion, soybean meal is the best while rapeseed remains behind.

The functional and technological properties of proteins from different species will be also a determining criterion, especially when uses are advanced from the point of view of nutrition (health food: Scenario 3 "Trust" and 4 "Climate rupture") and/or technology (use of vegetable protein in food industries for their functional qualities and as substitute for animal protein: scenarios 1 "Chaos", 2 "Blocks" and 4 "Climate rupture"). Today the characterization of plant proteins of species grown in Europe is still limited. These qualitative aspects also play in the ability of different species to meet the needs of aquaculture, which has a bright future in all scenarios.

As for oil crops, tensions on omega 3 should contribute to the competitiveness of species rich in alpha-linolenic acid (rapeseed, but also soybeans) on the edible oils market.

Other issues and challenges relate to some of the scenarios only.

Thus, the production of vegetable protein for human consumption is much higher in scenarios 1 "Chaos" and 4 "Climate rupture", and should quite naturally benefit pulses and soybean, which are already in the eating habits of many countries. The degradation of the protein balance of India is a remarkable point in all scenarios: the country may well become a structural importer of vegetable protein, including pulses which correspond to its food traditions.

Scenario 2 "Blocks", when Europe makes the choice of non-GMO, under the pressure of consumers, presents a huge challenge for supplying Europe with non-GMO protein, which would lead to make better use of the European territory with the most suitable species and production systems: the diversity of crop species - not GMOs - in Europe would be an advantage in this case. In this respect, the calculations show that achieving a balance between protein consumption and production is possible for Europe in 2030, particularly because of current developments in terms of eating habits (lower meat consumption) and demography (stabilization or decline in population).

But banning GMOs also disqualifies European oilseed rape from the supply of EPA and DHA long-chain polyunsaturated fatty acids, which would be likely produced in other regions.

The synthetic nitrogen fertilizer requirements for agricultural production would penalize rape, and sunflower to a lesser extent, and would favour grain legumes, forage legumes and soybeans in scenarios setting either carbon taxes (predictable rise in the cost of fertilizers (scenarios 2 "Blocks" and 4 "Climate rupture") or restrictive production standards on nitrogen and carbon energy (scenario 3 "Trust").

Developments related to climate change will play in contrasting ways in different parts of the world. In Europe, more stressful conditions than today are expected. Heat peaks and drier prolonged periods in spring and summer would disadvantage spring crops in rainfed conditions, including soybeans and pulses. Sunflower meanwhile has the advantage of some rusticity, but its compensation capabilities are limited. Milder and wetter winters would be unfavorable to winter rape, which is sensitive to water saturation, but, on the contrary, has significant compensation capabilities.

The future competitiveness of different crop species depends on many factors (economic, political, climatic, social, ...), who will play differently depending on the regions of the world, and whose the result is difficult to imagine. At the end of our reflection, we venture to offer a synthesis of the outlook for different species according to their current characteristics and without assuming the future success of any research and development measures (Tab. 5).

\section{Conclusions: Is the protein fraction the future of oilseeds?}

It seems clear that the economic value of the protein fraction is a key aspect of the future of oilseeds such as rapeseed, sunflower and soy. Indeed, The future tension for proteins at world scale appears quite certain: eventually, their value should increase, and this increase relates to 15 to $35 \%$ of the mass of oil-protein seeds .

At the first level of approach, the protein yields of the different crops will determine their competitiveness for mass uses, including animal feed. At the second level, the issue of nutritional and functional properties of proteins from oilseeds must be considered, with a large field of exploration to enhance uses with higher added value, in human nutrition, feed we may think aquaculture - and technology. From this point of view, soy is much more advanced than rapeseed, sunflower and grain legumes. The effective use of proteins from rapeseed and sunflower will also require technological research and adaptations of industrial extraction processes.

The relative value of the protein fraction of oilseeds may also increase if the value of the oil fraction does not, which is not a certainty. The scenario of the oil flood is a trend... if palm oil continues its dynamic development, and if the needed 
Table 5. Crops potential progression by 2030, based on their current features.

\begin{tabular}{|l|c|c|c|c|}
\hline $\begin{array}{l}\text { Crops potential progression } \\
\text { by 2030 }\end{array}$ & SC1 Chaos & SC2 Blocks & SC3 Trust & $\begin{array}{c}\text { SC4 Climate } \\
\text { rupture }\end{array}$ \\
\hline WORLD & & & & \\
\hline Rapeseed & - & ++ & + & - \\
\hline Sunflower & - & + & + & - \\
\hline Soyabean & ++ & +++ & ++ & ++ \\
\hline Grain legumes & ++ & +++ & ++ & + \\
\hline EUROPE & & & & \\
\hline Rapeseed & - & - & $=$ & -- \\
\hline sunflower & - & -- & - & -- \\
\hline Soyabean & +++ & +++ & ++ & +++ \\
\hline Grain legumes & + & +++ & +++ & +++ \\
\hline
\end{tabular}

proteins are produced mainly from processed soybean, which generates oil. Scenario 4 "climate rupture" appears just enough in vegetable oil despite limited non-food uses. The oil flood, and a depressed oil market, is not absolute certainty, especially if oleochemistry shows economic development in Asia. Vegetable oils are noble natural materials which may be used in many ways, the first one remaining human nutrition, for which rapeseed and sunflower oils have well-established nutritional qualities.

At last, we should keep in mind that the future will be determined in the capacity of crop chains to be proactive and to get used to the constraints imposed by the changing environment, whatever the origin, environmental, economic or regulatory. The work presented here does not provide definitive answers to the questions listed in the introduction but its only function is to shed light: in fact a scenario is not a prediction. Each scenario provides a picture of the opportunities that will draw the French and European oils and proteins productions, the constraints they will face or opportunities from which they can develop. In case it would happen, each scenario would necessitate strategies at least partly different, but some of which appear essential in all cases, that is to say, more robust for the future, and other potentially critical in some specific contexts. It is therefore the set of the 4 contrasting scenarios which constitutes both a toolkit to generate development policies for the crops value chains, and to assess the relevance and robustness in different contexts.

The diversity of oil and protein species is an advantage to this production sector, facing the challenges of 2030.

Acknowledgements. This work would not have been possible without the experts who shared their knowledge and insights in the working group, to whom we express our sincere thanks: Hilaire Bewa (ADEME), Pascal Cerneau (Groupe Avril), Jean-Michel Chardigny (INRA), Denis Chéreau (IMPROVE), Frédéric Fine (Terres Inovia),
Jacques Guéguen (INRA), Hubert Hébinger (Terres Inovia), Alain Huertas (Groupe Avril/Lesieur), François Luguenot (IN VIVO), Valérie Mazza (LIMAGRAIN), Alain Montembault (Terrena), Luc Ozanne (SOFIPROTEOL), Corinne Peyronnet (Terres Univia), Xavier Pinochet (Terres Inovia), Thierry Pouch (APCA/Univ. Reims), Michel Renard (INRA), Jean-François Rous (Groupe Avril). Also thanks to Anne-Marie Tremblay and Karim Ahmed Dhaouadi for their help and their contribution to this study.

\section{References}

Combris P. 2013. Les grandes tendances de l'alimentation dans le monde: les défis de la croissance. colloque PONAN, 29 novembre 2013, Nantes, France.

Godet M. 2007, Manuel de prospective stratégique. Paris: Dunod.

INRA-CIRAD. 2009. Agricultures et alimentations du monde en 2050 : scénarios et défis pour un développement durable. Rapport du groupe de travail Agrimonde.

Lecomte J, Pina M, Villeneuve P. 2013. Huiles et corps gras des Pays du Sud et lipochimie. OCL 20: 3-7.

Mittaine J-F, Mielke T. 2013. The globalization of international oilseeds trade. OCL 19.

Sébillotte C, Ruck L, Messéan M. 2002. Prospective : compétitivité des oléagineux dans l'avenir. OCL 9: 362-368.

Sébillotte C, Ruck L, Messéan M. 2004. Prospective : compétitivité des oléagineux dans l'avenir. $O C L$ 11: 5-10.

Sébillotte M, 2002. Apports et utilisation de la prospective "Protéines". OCL 9: 7-10.

Thomas A, Schneider A, Pilorgé E. 2013. Politiques agricoles et place du colza et du pois dans les systèmes de culture. Agron. Environ. Soc. 3.1, juin 2013. Available from: http://www.agronomie.asso.fr/.

De Visser C, Schreuder R., Stoddard F. 2014. The EU's dependency on soya bean import for the animal feed industry and potential for EU produced alternatives. OCL: D407.

Cite this article as: Etienne Pilorgé, Frédéric Muel. What vegetable oils and proteins for 2030? Would the protein fraction be the future of oil and protein crops? OCL 2016, 23(4) D402. 